Review article / Обзорная статья

DOI: http://dx.doi.org/10.21285/1814-3520-2020-6-1324-1336

\title{
On the question of using solid electrodes in the electrolysis of cryolite-alumina melts. Part 1.
}

\author{
Evgeniy S. Gorlanov \\ «EXPERT-AL» LLC, St. Petersburg, Russia
}

\begin{abstract}
This article is aimed at identifying issues associated with the use of solid cathodes in the electrolysis of cry olite-alumina melts in order to determine conditions for their practical application. The contemporary technology of using solid anodes and cathodes is reviewed from its inception to the present time. The problems of stable electrolysis are discussed, such as effects of the electrode surface on the technological process. It is shown that all attempts undertaken over the recent 100 years to use solid electrodes, both reactive and inert, have been challenged with the emergence of electrolysis instability, formation of precipitates of varying intensity on the electrodes and impossibility of maintaining a prolonged process at current densities of above $0.4-0.5 \mathrm{~A} / \mathrm{cm}^{2}$. Information is provided on the attempts to use purified electrolyte components with different ratios, metal-like and ceramic electrodes with a high purity and a smooth surface in order to approach real industrial conditions. However, to the best of our current knowledge, these experiments have not found commercial application. The authors believe that the most probable reason for the decreased current efficiency and passivation of solid electrodes consists in the chemical inhomogeneity and micro-defects of the bulk and surface structure of polycrystalline cathodes and anodes. It was the physical inhomogeneity of carbon electrodes that directed the development of the nascent electrolytic production of aluminium towards the use of electrolytic cells with a horizontal arrangement of electrodes and liquid aluminium as a cathode. This reason is assumed to limit the progress of electrolytic aluminium production based on the use of inert anodes and wettable cathodes in the designs of new generation electrolytic cells implying vertically arranged drained cathodes. The theoretical and experimental examination of this assumption will be presented in the following parts of the article.
\end{abstract}

Keywords: electrolysis, solid electrodes, physical heterogeneity, cathode passivation, inert anodes, wettable cathodes

For citation: Gorlanov ES. On the question of using solid electrodes in the electrolysis of cryolite-alumina melts. Part 1. Vestnik Irkutskogo gosudarstvennogo tehnicheskogo universiteta $=$ Proceedings of Irkutsk State Technical University. 2020;24(6):1324-1336. https://doi.org/10.21285/1814-3520-2020-6-1324-1336

УДК 620.181.4: 666.3-135

\section{К вопросу о применении твердых электродов для электролиза криолитоглиноземных расплавов. Часть 1.}

\author{
(ㄷ.С. Горланов \\ О०О «ЭКСПЕРТ-АЛ», г. Санкт-Петербург, Россия
}

Резюме: Цель - обозначение проблем и определение условий применения твердых катодов. Представлен обзор технологии электролиза криолитоглиноземных расплавов с использованием твердых анодов и катодов в историческом развитии - от ее изобретения и до настоящего времени. Обсуждаются проблемы стабильного ведения электролиза, но главным образом - влияние состояния поверхности электродов на технологический процесс. Показано, что все попытки использования твердых электродов, реактивных и инертных, на протяжении более 100 лет встречались с возникновением нестабильности электролиза, образования на электродах осадков различной интенсивности и невозможности ведения процесса в течение длительного периода при плотностях тока выше $0,4 \div 0,5 \mathrm{~A} / \mathrm{cm}^{2}$. Приведены данные, что для приближения к промышленным условиям исследователи пытались применять очищенные компоненты электролита с различным их соотношением, металлоподобные и керамические электроды с исходной высокой чистотой и гладкой поверхностью. Тем не менее, коммерческого выхода этим многочисленным попыткам в доступных источниках не обнаружено. В предлагаемой к обсуждению статье предполагается, что наиболее вероятной причиной уменьшения выхода по току и пассивации твердых электродов является химическая неоднородность и микродефектность объемной и поверхностной структуры поликристаллических катодов и анодов. Именно физическая неоднородность угольных электродов направила развитие зарождающейся технологии электролитического производства алюминия на применение электролизеров с горизонтальным расположением электродов и использование в качестве катода однородной поверхности жидкого 
алюминия. Эта же причина ограничивает развитие электролитического получения алюминия с использованием инертных анодов и смачиваемых катодов в конструкциях электролизеров нового поколения - с дренированными катодами и вертикальным расположением электродов. Развитие этого предположения, теоретическое и экспериментальное, будет обсуждаться в следующих частях статьи.

Ключевые слова: электролиз, твердые электроды, физическая неоднородность, пассивация катода, инертные аноды, смачиваемые катоды

Для цитирования: Горланов Е.С. К вопросу о применении твердых электродов для электролиза криолитоглиноземных расплавов. Часть 1. Вестник Иркутского государственного технического университета. 2020. Т. 24. № 6. C. 1324-1336. https://doi.org/10.21285/1814-3520-2020-6-1324-1336

\section{INTRODUCTION}

Attempts to develop an approach to the electrolysis of cryolite-alumina melts using solid electrodes have been ongoing since the inception of aluminium production. Such persistence can be explained, on the one hand, by the prospect of increasing the specific productivity of the process using vertically arranged electrodes in the limited volume of an electrolytic bath. On the other, there has always been a desire to minimize power consumption to the theoretically possible values of 6.242 and $9.162 \mathrm{kWh} / \mathrm{kg} \mathrm{Al}$ when using carbon and inert electrodes, respectively [1]. These values are assumed attainable under the polar-to-polar distance (PPD) of about $1.5 \div 2.0 \mathrm{~cm}$, which can be achieved only between solid electrodes. Nevertheless, for more than 130 years, the industrial production of aluminium has relied on electrolytic cells with a horizontal arrangement of electrodes and the use of the uniform surface of liquid aluminium as the cathode. Researchers in [2, 3] explained the long-term lack of progress in the commercial development of electrolysis based on inert electrodes by micro-defects of polycrystalline cathode surfaces. The results of these studies are generalized $\mathrm{in}^{1}$, but require further research under laboratory and industrial conditions. It is of primary importance to elucidate the causal relationship between the surface heterogeneity of electrodes, their passivation and the instability of the electrolysis process. This understanding can contribute to elaborating on the conditions of using solid cathodes. In this part of the article, we will discuss the pioneering works on the electrolytic production of aluminium and modern studies developing methods for the electrolysis of cryolite-alumina melts using solid electrodes through the prism of contemporary knowledge and achievements in the field.

\section{9th CENTURY}

It is common knowledge that the electrolytic production of aluminium from halide melts began with the use of solid electrodes. Among numerous methods for the electrolysis of molten salts at the end of the 19th century, only the methods proposed by Paul L.T. Héroult, Charles M. Hall and Adolphe Minet were of industrial importance. In fact, these researchers patented compositions of electrolytes based on cryolites and the dissolved aluminium oxide. In their first prospecting works, patents and industrial units, the authors used metal and carbon electrodes arranged vertically and parallel to each other in electrolytic cells.

$P$. Héroult submitted his first patent application on April 23, 1886 in France and registered it in September of the same year [4]. Later in 1887-88, the same process with minor modifications was patented in England and Belgium. According to this method, cryolite-alumina melts underwent electrolysis to yield aluminium. The walls of a graphite crucible served as the cathode; a cylindrical carbon anode was immersed in the melt in the centre of the cell, the temperature in which was maintained by an external source. Thus, in a crucible with a depth of $20 \mathrm{~cm}$ and an inner diameter of $14 \mathrm{~cm}$, at a current of $400 \mathrm{~A}$ and a voltage of $20-25 \mathrm{~V}$, relatively pure aluminium was obtained at current densities at the cathode and anode of $0.45 \mathrm{~A} / \mathrm{cm}^{2}$ and 1.70

\footnotetext{
${ }^{1}$ Gorlanov ES. Doping of cathodes used in aluminium electrolytic cells by a low-temperature synthesis of titanium diboride: Dissertaion for the Degree of Dr. Sci. in Engineering: 05.16.02. Saint-Petersburg, 2020. 391 р. / Горланов Е.C Легирование катодов алюминиевых электролизеров методом низкотемпературного синтеза диборида титана: дис. ... д-ра техн. наук: 05.16.02. СПб., 2020. 391 с.
} 
$\mathrm{A} / \mathrm{cm}^{2}$, respectively. Héroult mentioned no limitations of the presented electrolytic process, except for the resistance of the carbon crucible and the increased consumption of the anode.

Charles Hall filed his first patent application on July 9, 1886 under No. 207601 [5]. Hall patented an electrolytic cell with external heating and a carbon lining, in which the negative and positive electrodes were immersed vertically in the molten salt $\mathrm{NaF} \cdot \mathrm{AlF}_{3}\left(\mathrm{NaAlF}_{4}\right)$ with the addition of alumina under the cryolite ratio $(C R)=1$. After melting the dry salts, the electrolysis current was switched on. The anode was made either of carbon (to obtain pure $\mathrm{Al}$ ) or $\mathrm{Cu}, \mathrm{Pt}$ and other metals. It should be noted that, when a carbon anode was used, CO was released at the electrode. Conversely, the use of a copper anode resulted in the release of oxygen. In order to reduce the melting point, it was proposed to substitute some part of $\mathrm{NaF}$ with LiF. Aluminium at the cathode was reduced in the form of globules, which sank to the bottom of the crucible.

Since the productivity of an electrolysis unit working on this principle was rather low, Hall continued to improve his method. In an additional application No. 226206 submitted on February 2, 1887, Hall presented a different electrolyte composition - $\mathrm{KF} \mathrm{AlF}_{3}\left(\mathrm{KAIF}_{4}\right)$ with alumina $(\mathrm{CR}=1)$ [6]. The optimal voltage across the cell was indicated to equal 3-4 V. Similar to the previous application, the possibility of using the walls of a carbon crucible as the cathode was confirmed, thus resembling Heroult's patent in its key aspects.

Continuous testing of the proposed method failed to solve issues associated with unstable electrolysis. In his next application No. 282954 dated August 17, 1888 Hall noted that, when using the electrolyte composition according to the previous patents, a black or dark substance would form in the near-cathode electrolyte. This substance impeded electrolysis, increasing the electrical resistance in the system and requiring frequent renewal of the melt [7]. Therefore, the purpose of the patented invention was to provide an electrolyte composition, under which electrolysis could be carried out continuously without adjusting the current and terminating the electrolysis. It was proposed to use the compositions $\mathrm{CaF}_{2} \cdot 2 \mathrm{AlF}_{3}\left(\mathrm{CaAl}_{2} \mathrm{~F}_{8}\right)$ and $3 \mathrm{CaF}_{2} \cdot 2 \mathrm{AlF}_{3}$
$\left(\mathrm{Ca}_{3} \mathrm{Al}_{2} \mathrm{~F}_{12}\right)$ with the addition of $\mathrm{BaAl}_{2} \mathrm{~F}_{8}$ and $\mathrm{SrAl}_{2} \mathrm{~F}_{8}$. These compositions were heavier than metal, thus allowing aluminium to be floating on the surface. Therefore, a carbon baffle was needed between the anode and cathode regions to protect the cathode from oxidation. At the same time, to reduce the density of the electrolyte, it was proposed to add $2 \mathrm{KF} \cdot 2 \mathrm{AlF}_{3}\left(\mathrm{~K}_{2} \mathrm{Al}_{2} \mathrm{~F}_{8}\right)$ to the ready-made compositions in the amount of $2 / 3$ of its weight. Then the obtained aluminium would remain under the melt, requiring no baffle. It should be mentioned that, according to the scheme proposed by Hall, the size and, therefore, the entire cathode area was much smaller than that of the anode. This meant that the current density at the cathode was higher than that at the anode. Perhaps Hall provided for a possibility of working at lower anode densities to reduce anode consumption.

According to the supplementary patent application No. 282955 also filed on August 17 in 1888 , a black precipitate was largely formed in an electrolyte consisting of sodium and aluminium fluorides rather than in that consisting of potassium, calcium and aluminium fluorides [9]. In this regard, Hall proposed to use the melt composition $\mathrm{Na}_{2} \mathrm{Al}_{2} \mathrm{~F}_{8}+\mathrm{CaAl}_{2} \mathrm{~F}_{8} \quad\left(\mathrm{NaF} \cdot \mathrm{AlF}_{3}+\right.$ $\mathrm{CaF}_{2} \cdot 2 \mathrm{AlF}_{3}=\mathrm{NaF} \cdot \mathrm{CaF}_{2} \cdot 2 \mathrm{AlF}_{3}$ ), i.e. with a molar ratio of $\mathrm{CR}=0.5$. This composition is characterized by a lower density than aluminium, which allowed the metal to sink to the bottom of the crucible. It was noted that addition of aluminium oxide in amounts larger than could be dissolved was not problematic, since its excess would deposit at the bottom in the form of a precipitate and would be consumed upon its lack in the electrolyte. The electrolytic cell was operated at a voltage of about $6 \mathrm{~V}$, although larger voltage ranges were also possible.

Charles Hall registered his last application in this series (No. 286034) on September 21, 1888 [9]. It was noted that the disruption of the process began with passivation of the carbon cathode. Thus, under the same conditions and the use of the same electrolytes, metal cathodes did not passivate. Following numerous experiments, Hall concluded that the stability and the very possibility of electrolysis depended on the electrolyte composition. In this regard, it was proposed to use electrolytes of compositions speci- 
fied in his previous applications, but with the addition of 3-4\% wt. calcium chloride, in the presence of which the process would proceed without noticeable decomposition of the electrolyte at a voltage of $4-8 \mathrm{~V}$.

In this brief review of Héroult's and Hall's methods, we deliberately drew attention to the stability of cathodic processes and the entire electrolysis of molten salts. The design of Heroult's electrolytic cell, in which a carbon cathode was operated at current densities lower than $0.5 \mathrm{~A} / \mathrm{cm}^{2}$, allowed a stable process under laboratory conditions with a rise of up to $400 \mathrm{~A}$. Conversely, in Hall's designs with equal geometric current densities at the anode and cathode (the current intensity was not indicated), the process was unstable and was followed by passivation of the carbon cathode with dark precipitates. It can be assumed that the use of an electrolyte composition with a cryolite ratio of $0.5-$ 1.0 and a corresponding low solubility of aluminium oxide, an insufficient content of dissolved alumina in the melt made the electrolytic cell operate at limiting values of diffusion current densities. In that case, the cathode potential shifted towards more electronegative voltages (without changing the total current) up to the decomposition potentials of the electrolyte components. It goes without saying that the composition of the electrolyte with a low CR had a significant effect on the stability of the entire process. However, Hall noted that, in the same electrolytes, the process was stable when using metal cathodes. In this regard, we cannot assume any other reason for the instability of electrolysis and passivation of the carbon cathode, except for the condition of the cathode surface, i.e. the physical inhomogeneity of the electrode surface (pores, irregularities, cold shuts, scratches and other defects). It is known that the electrical engineering industry was only at the beginning of its development at that time. It was impossible to purchase carbon electrodes with a diameter of more than $50 \mathrm{~mm}$, and the available carbon products were of low quality.

On the basis of these preliminary findings, it becomes possible to explain the results obtained by Adolphe Minet, a famous French researcher and electrical engineer. In 1887 and 1888, at the Bernard Bros. at Creil, Minet exper- imented with the electrolysis of cryolite-alumina melts containing sodium chloride, producing about $15-20 \mathrm{~kg}$ of aluminium per day [10]. In fact, his process and industrial units differed from those proposed by Hall and Héroult only by the addition of $\mathrm{NaCl}$ to the electrolyte. However, unlike his colleagues, Minet investigated not only electrolysis, but also conducted systematic theoretical studies under laboratory and industrial conditions. In particular, he investigated the dependence of current efficiency (CE) on current density and cathode material. Small laboratory cells with iron cathodes, which were operated for 12-24 hours at current densities of up to $0.5 \mathrm{~A} / \mathrm{cm}^{2}$ and voltages of $5.5-5.75 \mathrm{~V}$, produced the CE of no more than $52 \%$. However, when carbon cathodes were used, the CE of about $75 \%$ was achieved. The opposite situation was observed when the current density was raised above $0.5 \mathrm{~A} / \mathrm{cm}^{2}$. Then the CE on carbon cathodes did not exceed $52-54 \%$, although this indicator ranged from 68 to $82 \%$ in cells with iron cathodes. These findings were confirmed on semi-industrial electrolytic cells with a current of $3000 \mathrm{~A}$. The only difference was that, at higher current densities, the values of current efficiency depended more strongly on the cathode material used: the application of carbon cathodes resulted in the CE of $66-70 \%$, while iron electrodes made it possible to reach $\mathrm{CE}=90 \%$. Generalizing the results of his experiments, Minet assessed the electricity consumption for the production of $1 \mathrm{~kg}$ of aluminium at the level of 32 and $23 \mathrm{kWh}$ for carbon and iron cathodes, respectively. Unfortunately, the author did not provide any explanation for these results. However, the current level of knowledge about the influence of the cathode surface on electrochemical processes [11-14] allows us to propose the following assumption. At a low geometric current density (in our case, up to $0.5 \mathrm{~A} / \mathrm{cm}^{2}$ ), its uneven distribution over the surface of polycrystalline electrodes does not approach critical levels, i.e. the limiting current density. The cathodic process proceeds in a stable diffusion mode with a potential that ensures the discharge of the target melt components - aluminium ions. On a carbon cathode with surface micro-defects, the actual current density will be higher than that on a relatively uniform surface of an iron cathode. There- 
fore, the rate of the process, and hence the aluminium output over a particular time period will be higher. This situation changes when a certain current density is exceeded (in our case, 0.5 $\mathrm{A} / \mathrm{cm}^{2}$ ). An increase in current density intensifies its non-uniform distribution, similar to the corresponding current concentration on the defects of the surface structure - on the peaks or sharp edges of pores and irregularities. In this case, the current density at the carbon cathode can reach the limiting value not only for the discharge of aluminium ions, but also for more electronegative ions, e.g., calcium. Under an avalanche-like development of the process, a simultaneous discharge of electronegative impurities (sodium, calcium) and the decomposition of aluminium fluoride and cryolite are possible, followed by partial or complete passivation of the electrode. When describing the course of electrolysis, Minet did not indicate problems associated with the stability of the process; however, a moderate manifestation of these effects, i.e., current consumption for inappropriate reactions, could lead to an overestimated power consumption and an underestimated current efficiency when using carbon cathodes. In conclusion, let us emphasize that, in 1890, a more powerful electrolysis plant was built in SaintMichel, Savoy, based on Minet's method. By 1894, this plant had been producing $450 \mathrm{~kg}$ of aluminium per day. However, the facility was transferred to Hall's process in 1895, reportedly due to the relatively high cost of production.

It is essential to understand the reasons explaining the popularity and spread of Hall's technology and industrial units in the USA, Canada and Europe. Note that two patent applications dated 1886 and 1887 refer to the period of Hall's work in his own laboratory (table).

The other three applications, AugustSeptember 1888, were submitted immediately after the severance of Hall's relations with the Electric Smelting and Aluminium $\mathrm{Co}^{\circ}$ (Cowles brothers), operating in Lockport, NY (Lockport, NY). This breakup was triggered by the unsatisfactory results of Hall's experiments on a small scale, and the additional patent applications were aimed at eliminating the flaws in the process. Having registered applications for the production of aluminium by an electrolytic method,
Hall went to Pittsburgh in September 1888 to negotiate the establishment of the Pittsburgh Reduction Company (PRC) - the predecessor of Alcoa. The owners immediately began the construction of the plant, which had been producing 22-23 kg of aluminium per day by November 1888. The electrolytic cells were small cast iron baths (cathode casing) with the dimensions of $60 \times 40 \mathrm{~cm}$ and a depth of $50 \mathrm{~cm}$, lined inside with carbon plates $75 \mathrm{~mm}$ thick and containing up to $90-136 \mathrm{~kg}$ of electrolyte (figure) [15]. The electrolyte level was about $15 \mathrm{~cm}$ with a cryolite ratio $\mathrm{NaF} / \mathrm{AlF}_{3}=1$.

Eight cylindrical carbon anodes $(8 \mathrm{~cm}$ in $\mathrm{di}$ ameter) in two rows were suspended from above on copper current leads $1 \mathrm{~cm}$ in diameter. Each of the anodes received from 220 to $250 \mathrm{~A}$; a total of $1800 \mathrm{~A}$ of direct current was supplied to the reduction cell. The soles of the anodes were kept from the bottom at a pole-to-pole distance (PPD) of 1.3-2.6 cm, but the voltage was maintained at about $8 \mathrm{~V}$. To reduce the consumption of fluorine salts and to protect the anodes from oxidation, carbon powder (covering material) was poured on the electrolyte surface with a layer of $2-3 \mathrm{~cm}$. The productivity of such electrolytic cells was up to $12 \mathrm{~kg} \mathrm{Al} /$ day with an anode consumption of $1 \mathrm{~kg}$ and an energy consumption of about $30 \mathrm{kWh}$ per $1 \mathrm{~kg}$ of Al produced. The service life was about several weeks, during which the electrodes were passivated by precipitation causing unstable operation of the electrolytic cells.

The above-described scheme exhibits several inconsistencies related to current density, electrolyte level and cell voltage. For example, if it is assumed that all the current passed between the lower plane of the anode and the cell floor, the anode current density at the bottom was about 5-6 A/cm ${ }^{2}$ and the cathode current density ranged from 0.75 to $1.0 \mathrm{~A} / \mathrm{cm}^{2}$. At the same time, it is obvious that not only the cell floor could serve as the cathode surface, but also the carbon walls of the side lining, the distance from the anodes to which was about $8 \mathrm{~cm}$. This partly explains the increased operating voltage; however, the actual anode and cathodic current densities are difficult to estimate. On the other hand, if the electrolyte level did not exceed $15 \mathrm{~cm}$, its amount would have corresponded 
Charles Hall's patents obtained during 1886-89

Патенты Ч. Холла в период 1886-1889 гг.

\begin{tabular}{|c|c|c|c|}
\hline No. pp & Application No./date & Patent No. $^{*}$ & Patent name \\
\hline 1 & $207601 / 07.09 .1886$ & 400766 & Process of reducing aluminium by electrolysis \\
\hline 2 & $226206 / 02.02 .1887$ & 400664 & Process of reducing aluminium from its fluoride salts by electrolysis \\
\hline 3 & $282954 / 17.08 .1888$ & 400665 & Manufacture of aluminium \\
\hline 4 & $282955 / 17.08 .1888$ & 400666 & Process of electrolyzing crude salts of aluminium \\
\hline 5 & $286034 / 09.21 .1888$ & 400667 & Process of electrolyzing fused salts of aluminium \\
\hline
\end{tabular}

${ }^{*}$ All the patents were registered simultaneously on April 2, 1889 / Все патенты зарегистрированы одновременно 2 апреля 1889 г.

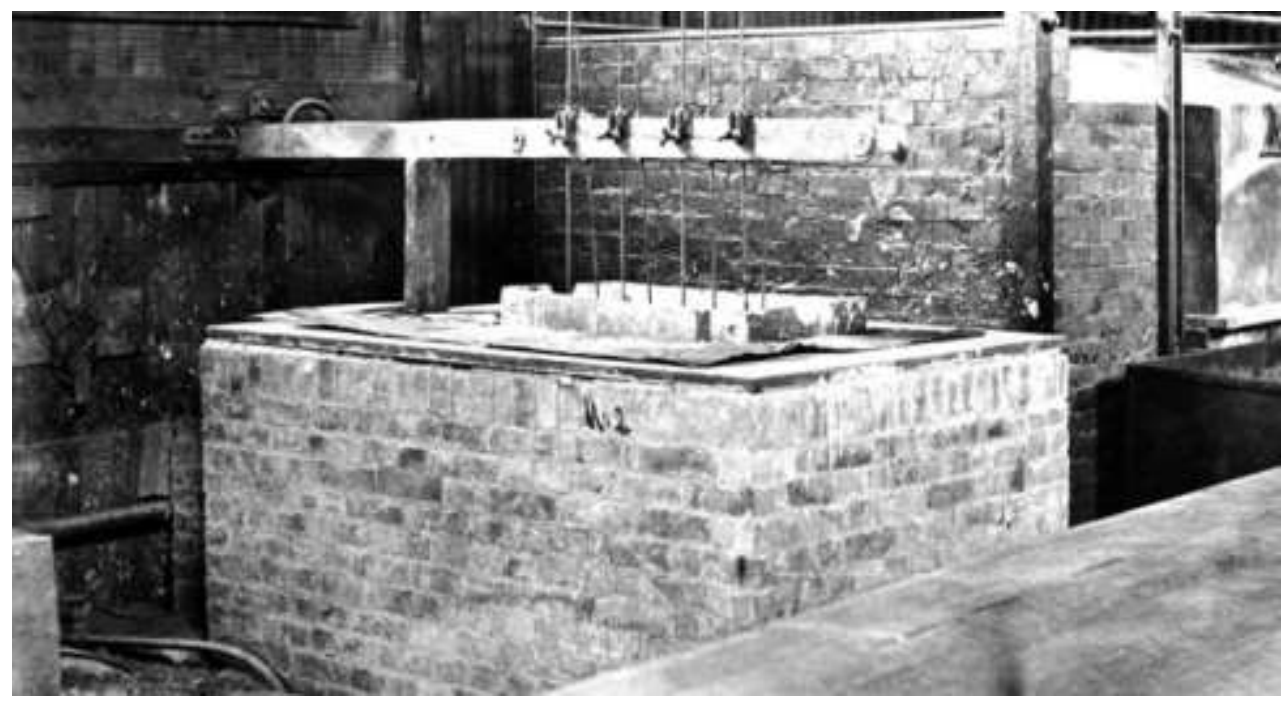

Pittsburgh Reduction Company cells in 1888 (Pittsburgh, Smallman Street plant) [16] Электролизеры Pittsburgh Reduction Company 1888 2. (Pittsburgh, Smallman Street plant) [16]

to lower values of about $50-55 \mathrm{~kg}$, rather than 90-136 kg. In other words, it is obvious that the first industrial electrolytic cells, having a cell depth of $50 \mathrm{~cm}$, comprised a liquid aluminium cathode. Then it becomes possible to explain the increased consumption of anodes and a rather high daily output of aluminium, as well as the decision of stockholders in 1990 to expand the plant switching to larger electrolytic cells of $10 \mathrm{kA}$.

Why are we discussing Hall's laboratory tests in such detail, as well as his patents for the method of electrolytic production of aluminium and the first steps of the aluminium industry? First, at the stage of making a decision to implement his experiments in practice, Charles Hall took advantage of his patents and chose the option of an electrolysis cell with an anode in the centre of the bath and the cathodic surface of the crucible. In all of his five patents, this construction design was not the major feature and coincided exactly with Héroult's patent decisions. Secondly, even before the introduction of the method into practice, in 1888, Hall, PRC stockholders and factory specialists abandoned the idea of using solid cathodes, which failed to ensure stable operation of electrolytic cells. It was with this collective stockholder decision that the Pittsburgh Reduction Company laid the foundations for the modern aluminium production process. In this regard, and thirdly, the development of a new method of the electrolysis of cryolite-alumina melts using a uniform surface of liquid aluminium as the cathode, revised electrolyte compositions and other technical and design solutions gave aluminium companies grounds to restrict access to their plants to outside specialists. In the late 19th and early 20th centuries, European and American aluminium plants became the most closed industrial enterprises inaccessible for visiting [17].

\section{0th CENTURY}

In the subsequent pre-war and post-war years, some attempts to return to the use of solid cathodes were made $[18,19]$. These attempts failed at the stage of obtaining patents, since 
carbon electrodes are not wettable with aluminium. Interest in cell designs using solid cathodes revived in the 1950s after the publication of Ch.E. Ransley's patents on the use of borides and carbides of refractory metals, which are wettable with aluminium and resistant to aggressive working environments, as cathode materials [20-22]. Although these inventions have not found commercial application, numerous studies were carried out to employ the unique properties of products and coatings based on carbides and borides of refractory metals in the designs of conventional aluminium reduction cells and new generation reduction cells with drained cathodes and vertically arranged electrodes [23-30]. Investigations of compact products made of titanium diboride $\left(\mathrm{TiB}_{2}\right)$ or its composites demonstrated not only their effectiveness but also their vulnerability associated with increased cracking as a result of inter-granular corrosion and a relatively rapid wear.

When developing a technology for using vertically arranged inert electrodes, researchers faced a more serious problem (which was familiar at the time to Charles Hall). This problem was associated with aluminium-wetted cathodes based on titanium diboride, rather than with inert anodes. The work of C.W. Brown published in 1998 [31] reported the results obtained by Theodor Beck, whose first series of experiments with the electrolysis of low-melting potassiumsodium electrolytes with increased alumina content at $700^{\circ} \mathrm{C}$ resulted in passivation of $\mathrm{TiB}_{2}-$ cathodes with a grey or white sediment. Aluminium was found in the cell in the form of small spheres. The author found these results perplexing.

The following series of experiments was undertaken to elucidate the behaviour of $\mathrm{TiB}_{2}$ based cathodes at $750^{\circ} \mathrm{C}$ in low-temperature electrolytes (NaF:44\%A1F 3 and

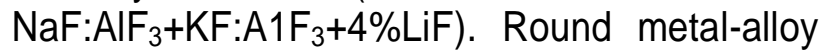
anodes were placed at the bottom of the cell made of corundum with a volume of $500 \mathrm{ml}$. Cathodes of two types were placed above the anodes in the cell. The first type was a pure hot- pressed $\mathrm{TiB}_{2}$ produced from a tank armour plate supplied by Ceradyne. The second type was a composite with graphite, designated as $\mathrm{TiB}_{2}$ $10 \% \mathrm{G}$, provided by the Great Lakes Carbon company. For each test, fresh diamond-polished cathode specimens were used. The current density, cathode and electrolyte compositions were varied. The anode current density was maintained within $0.13-0.5 \mathrm{~A} / \mathrm{cm}^{2}$. The tests were carried out at three cathode current densities by changing the cathode surface area $0.08 \mathrm{~A} / \mathrm{cm}^{2}, 0.3 \mathrm{~A} / \mathrm{cm}^{2}$ and $1.2 \mathrm{~A} / \mathrm{cm}^{2}$, depending on which the experiment lasted for 320,80 and 20 minutes, respectively.

After all the experiments, the cathode was found to be covered with a thin layer of Al, but there was always a grey or black electrolyte layer on top of the aluminium. This sediment was of two types. The first type was present only on $\mathrm{TiB}_{2}-\mathrm{G}$ cathodes operating at high current densities. This grey and hard residue could not be removed from the electrode surface. Visually, aluminium was absent on these cathodes, but energy dispersive spectroscopy discovered a thin layer of aluminium between the cathode and the deposit, which consisted of cryolite. All other cathodes had a mixed, relatively soft layer of grey electrolyte with black inclusions and aluminium.

Beck reported additional observations, according to which the formation of sediments decreased at low current densities and increased alumina concentrations. No residue was formed at temperatures above $800^{\circ} \mathrm{C}$. Based on the experimental results and these observations, it was concluded that the cathodes passivated due to insufficient dissolution of aluminium oxide.

However, the results of the conducted EDS analysis, i.e. the presence of a thin layer of aluminium between the cathode and the passivated deposit, may indicate the cathode operation at the limiting current densities in terms of aluminium and the potential shift up to the values of the decomposition voltage of the electrolyte components:

$$
\begin{array}{cc}
\mathrm{AlF}_{3}+3 / 4 \mathrm{C}=\mathrm{Al}+3 / 4 \mathrm{CF}_{4}, & \mathrm{E}_{\mathrm{p}}^{0}=2.144 \mathrm{~V} ; \\
\mathrm{Na}_{3} \mathrm{AlF}_{6}+3 / 4 \mathrm{C}=\mathrm{Al}+3 \mathrm{NaF}+3 / 4 \mathrm{CF}_{4}, & \mathrm{E}_{\mathrm{p}}^{0}=2.520 \mathrm{~V}
\end{array}
$$


It should be noted that preliminary polishing of cathode samples gives a short-term effect, since an intercrystalline oxide phase formed during manufacture and/or heating is always present on both the surface and in the bulk. Upon interaction with the electrolyte, these oxides, oxyborides and oxycarbides dissolve followed by the formation of progressive physical surface heterogeneity. Therefore, Beck's observations can be interpreted from the standpoint of uneven distribution of the current and potential over the cathode surface. This non-uniform distribution decreases with a decrease in the total load on the electrodes, since an increase in temperature decreases the viscosity of the melt, thus removing restrictions on mass transfer.

When developing a technology of new generation reduction cells comprising vertical electrodes at the turn of the 1990s and 2000s, specialists at the Alcoa research centre noted the emergence of problems associated with the operation of cathodes from hot-pressed $\mathrm{TiB}_{2}$, rather than with the operation of low-consumable anodes. Unfortunately, the information from Alcoa was very limited and not informative [32]. Although the essence of the problem was not disclosed, the company reported on the presence of oxides in dense cathode products, which appeared at the stage of their manufacture, in the process of firing and starting the bath. It seems obvious that the problem lies not only in the high cost of titanium diboride products, but also in the peculiarities of cathodic processes on solid polycrystalline cathodes during the electrolysis of cryolite-alumina melts.

\section{1st CENTURY}

A more informative report was issued in 2005 by the Northwest Aluminium Technologies (NAT) on a 4-5 year experience of working on the same issue [33]. Metallic $\mathrm{Cu}-\mathrm{Ni}-\mathrm{Fe}$ anodes and $\mathrm{TiB}_{2}$ cathodes were used in 200 to $5000 \mathrm{~A}$ electrolytic cells operating at a current density from 0.25 to $1 \mathrm{~A} / \mathrm{cm}^{2}$ in experiments lasting for 5-300 h. Standard problems were noted for $\mathrm{TiB}_{2}$ cathodes, with the major problems concerning the formation of sediments and passivation of the cathode surface at current densities of above $0.5 \mathrm{~A} / \mathrm{cm}^{2}$. Among the underlying reasons for these phenomena were mentioned the porous structure and presence of titanium oxides on the surface and in the bulk of the cathodes. The conclusion was made that hot-pressed cathodes made of titanium diboride were unsuitable for commercial use. In a postscript, Dr Bradford, the author of the NAT report, concludes: "Therefore, the most important condition for the successful operation of the system under development is the creation of cathodes suitable for long-term use in the technology of inert anode with low-temperature electrolytes."

A study published in 2007 [34] investigated the behaviour of inert anodes in a conventional electrolyte at $960^{\circ} \mathrm{C}$ and in low-temperature electrolytes $\mathrm{KF}^{-\mathrm{AlF}_{3}}$ and $\mathrm{K}_{3} \mathrm{AlF}_{6}-\mathrm{Na}_{3} \mathrm{AlF}_{6}-\mathrm{AlF}_{3}$ at $700-800^{\circ} \mathrm{C}$. It was observed that the electrolysis was more stable in a readily-fusible electrolyte at $800^{\circ} \mathrm{C}$, whereas significant voltage fluctuations (5.96-19.6 V) associated with the formation of a passivating sediment on the cathode were noted at $700^{\circ} \mathrm{C}$. Similar observations were recorded at the Institute of High-Temperature Electrochemistry of the Ural Branch of the Russian Academy of Sciences [35].

Low-temperature electrolysis with the use of KF-AIF potassium electrolytes, $\mathrm{CR}=1.3$ and the working temperature of $700-770^{\circ} \mathrm{C}$ was investigated in ${ }^{2}$ [36]. In some experiments, sodium fluoride was added to a potassium electrolyte. The concentration of alumina was maintained at the level of $4.5-5.5 \% w t$. All the experiments used electrolytic cells operated at 20 and $100 \mathrm{~A}$ with vertically arranged anodes and cathodes. Aluminium bronze was used as the anode, while the cathode was composite $\mathrm{TiB}_{2}-\mathrm{C}$. The distance between the cathode and anode plates was $2 \mathrm{~cm}$. The proposed experimental cell implied the use of a vertical anode in the centre and two cathodes on the sides. According to the scheme, all electrodes were of the same size in section. The paper specified the size of the anodes, as well as the anode and cathode densi-

\footnotetext{
${ }^{2}$ Tkacheva OYu. Low-temperature electrolysis of alumina in fluoride melts: Dissertation for the degree of Dr. Sci. in Chemistry: 05.17.03. Ekaterinburg, 2013. 24 р. / Ткачева О.Ю. Низкотемпературный электролиз глинозема во фторидных расплавах: дис. ... д-ра хим. наук: 05.17.03. Екатеринбург, 2013. 245 с.
} 
ties of $0.45 \mathrm{~A} / \mathrm{cm}$ and $0.52 \mathrm{~A} / \mathrm{cm}$, respectively. The size of the cathodes and the approach used for maintaining the electrode load were not given, thus hampering the analysis of the published data. A 1.5-litre corundum crucible was used as a container. During the electrolysis, the voltage on the bath, current, temperature, anode and cathode potentials were recorded using the Labview software at a rate of 1 measurement per second. During the entire experiment, the voltage increased from 5.5 to $8.5 \mathrm{~V}$. Even the disconnection of the current (for the dissolution of the anode film as stated) did not lead to a decrease in voltage. After the experiment, the cathode was found to be covered with a thick layer of a grey substance (cake), which showed the presence of only $\mathrm{KAIF}_{4}$ and $\mathrm{K}_{3} \mathrm{AlF}_{6}$ according to X-ray analysis. No aluminium oxide was found. According to the authors [36], the sediment on the cathode was to be associated with the enrichment of the near-electrode region with potassium fluoride, the increase in CR and, as a result, its melting temperature. Eventually, the electrolyte "freezes" on the cathode surface, thus passivating it. Therefore, an increase in electrolysis temperature removes the sediment from the cathode and normalizes the process.

In our opinion, an increase in temperature is capable of melting the sediment on the cathode formed for other reasons as well, e.g., due to a decrease in the electrolyte viscosity and an improved hydrodynamics of the melt in the polar space. Moreover, the cathode process in these experiments, considering the proposed scheme (anode in the centre, cathodes on the sides), took place at reduced current densities. In addition, all the parameters - the process temperature, the solubility of aluminium oxide and the electrolysis stability - were directly proportional.

Similar results were presented in 2018 following a series of large-scale laboratory studies of electrolysis in a cell with vertical electrodes [37]. Inert ceramic materials were used as anodes; cathodes were prepared from composite $\mathrm{TiB}_{2}-\mathrm{C}$. For a molten environment, a low-floating electrolyte $\mathrm{KF}-\mathrm{NaF}-\mathrm{AlF}_{3}$ was prepared by mixing the corresponding quantities of sodium cryolite, potassium fluoride and alumina of industrial varieties. After the mixture had been melted, the KF content was about $20 \%$ wt; the ratio
$[\mathrm{NaF}]+[\mathrm{KF}] / /\left[\mathrm{AlF}_{3}\right]$ was $1.4-1.5$; and the alumina content was $4.2-5.3 \%$ wt. In experiments with a current density of $0.07 \mathrm{~A} / \mathrm{cm}^{2}$, no aluminium on the cathode was observed. In experiments with a current density ranging from 0.15 to 0.26 $\mathrm{A} / \mathrm{cm}^{2}$ and stable electrolysis parameters, a dense layer of aluminium was formed on the wetted surface. However, when the current density was raised above $0.4 \mathrm{~A} / \mathrm{cm}^{2}$, the process destabilized, leading to a dramatic decrease in current efficiency. A layer of electrolyte components and aluminium carbide was formed on the cathode. The authors [37] reasonably explained this situation with a local increase in the cryolite ratio in the near-electrode layer due to an increase in the polarization of the cathode, under which values the discharge of $\mathrm{Na}$ and $\mathrm{K}$ ions was intensified.

However, sodium and potassium in atomic form are capable of interacting with the cathode material followed by micro-degradation of its surface. This was confirmed by the work [38], which examined the interaction between $\mathrm{Na}$ and hot-pressed cylindrical samples of $\mathrm{TiB}_{2}$ in an installation for thermogravimetric analysis. $\mathrm{TiB}_{2}$ showed a high reactivity with regard to gaseous $\mathrm{Na}$. The weight gain after a 72-hour exposure to sodium vapours was 0.26 and $0.43 \mathrm{wt} \%$ at $750^{\circ} \mathrm{C}$ and $850^{\circ} \mathrm{C}$, respectively. At the same time, visually, the sample had no clear changes in size, although changing its colour from greyish to black. According to EDS analysis, the surface black layer of 30-40 microns thick consisted mainly of $\mathrm{Ti}, \mathrm{Na}$ and $\mathrm{O}$. Noteworthy, the dense phase in the titanium diboride surface layer was sodium borate with the formula $\mathrm{NaBO}_{2}$, while the upper porous phase consisted of sodium oxides and titanium. This means that $\mathrm{Na}$ and oxygen are involved in the reaction with $\mathrm{TiB}_{2}$. According to the authors, this process under the experimental conditions $\left(750^{\circ} \mathrm{C}\right)$ takes place according to the following scheme:

$$
\begin{gathered}
\mathrm{TiB}_{2}+8 \mathrm{Na} \text { (gaseous) }+4.5 \mathrm{O}_{2} \text { (gaseous) } \rightarrow \\
\mathrm{Na}_{4} \mathrm{TiO}_{4}+\mathrm{Na}_{4} \mathrm{~B}_{2} \mathrm{O}_{5} \text { (liquid) } \\
\Delta \mathrm{G}_{\mathrm{T}}^{0}=-3528.4 \mathrm{~kJ} / \mathrm{mol}
\end{gathered}
$$

The authors [38] noted that, in an industrial electrolytic cell, the formed liquid borate phases would dissolve in the electrolyte, thus exposing 
the new surface to the next decomposition cycle. This would lead to a continuous degradation of the cathode. If these effects were limited solely to the cathode surface corrosion, which might be acceptable for the commercial use of titanium-diboride-based electrodes, the development of inert cathode technology could be considered a success. However, the problem of surface corrosion and the associated increased physical and chemical heterogeneity of the cathode surface can be a serious obstacle to ensuring a normal process of electrolysis.

\section{CONCLUSION}

On the basis of the presented analysis of available publications, we attempted to establish a functional connection between various electrolysis parameters and the state of the electrode surface in the context of historical evolution of this research field. During the development of electrolysis of cryolite-alumina melts using solid electrodes, both contemporary researchers and 19th-century scientists observed and sought to overcome the same problems, i.e. increased consumption and dissolution of anodes, passivation of cathodes and disruption of the electrolytic process. In the 19th century, this problem was solved by the use of liquid cathodes and horizontally arranged electrodes. Despite the high production costs, particularly electricity, this approach was justified by an extremely high demand in aluminium. Therefore, in the 20th century, researchers aimed to improve this method by increasing the unit capacity of electrolytic cells. In today's world, with its severe environmental constraints and threatening energy shortages, a return to the origins of the aluminium industry seems possible. It is hoped that all the problems of electrolysis on solid electrodes could be solved by accumulated knowledge, new materials and automated technological procedures. This requires additional theoretical investigations and experimental studies, which will be described in the following parts of the article devoted to the specific features of electrolysis using solid electrodes - reactive and inert cathodes and anodes.

\section{References}

1. Solheim A. Inert anodes - the blind alley to environmental friendliness? Light metals. 2018;1253-1260. http://doi.org/10.1007/978-3-319-72284-9_164

2. Gorlanov ES. Electrolysis of cryolite-alumina melts on solid cathodes. In: XI Mezhdunarodnyj kongress «Cvetnye metally i mineraly» i XXXVII Mezhdunarodnaya konferenciya "IKSOBA»: sbornik dokladov = XI International Congress "Non-ferrous Metals and Minerals" and XXXVII International Conference "IKSOBA": Collected reports. 16-20 September 2019, Krasnoyarsk. Krasnoyarsk; 2019, p. 275-288. (In Russ.)

3. Gorlanov ES. Features of solid electrode application for cryolite-alumina melt electrolysis. Vestnik Irkutskogo gosudarstvennogo tehnicheskogo universiteta = Proceedings of Irkutsk State Technical University. 2019;23(2):356-366. (In Russ.)

http://doi.org/10.21285/1814-3520-2019-2-356-366

4. Héroult PLT. Procédé électrolytique pour la préparation de l'aluminium. Patent FR, no. 175711; 1886.

5. Hall CM. Process of Reducing Aluminum by Electrolysis. Patent US, no. 400766; 1889.

6. Hall CM. Process of reducing aluminium from its fluoride salts by electrolysis. Patent US, no. 400664; 1889.

7. Hall CM. Manufacture of aluminium. Patent US, no. 400665; 1889.

8. Hall CM. Process of electrolyzing crude salts of aluminium. Patent US, no. 400666; 1889.

9. Hall CM. Process of electrolyzing fused salts of alumin- ium. Patent US, no. 400667; 1889.

10. Minet A. The Production of Aluminium and its Industrial Uses. First edition. London: Chapman \& Hall; 1905, $266 \mathrm{p}$.

11. Ibl N. Current Distribution. In: Comprehensive Treatise of Electrochemistry. Vol. 6. Electrodics: Transport. Eds. by E. Yeager J.O'M. Bockris, B.E. Conway, S. Sarangapani. New York: Plenum Press; 1983, p. 239-315. Available from:

https://books.google.ru/books/about/Electrodics_transport. html?id=aN-FAAAAIAAJ\&redir_esc=y [Accessed 9th August 2020].

12. Newman J, Thomas-Alyea KE. Electrochemical systems. 3rd ed. John Newman and New Jersey. Hoboken: John Wiley \& Sons; 2004, 647 p.

13. Gamburg YuD, Zangari G. Theory and Practice of Metal Electrodeposition, 2015. 441 p. (Russ. ed.: Teoriya $i$ praktika elektroosazhdeniya metallov. Moscow, BINOM, Laboratoriya znanij, 2015, 441 p.)

14. Baraboshkin NA. Electrocrystallization of metals from molten electrolytes. Moscow: Nauka; 1976, 279 p. (In Russ.)

15. Richards JW. Aluminium: its history, occurrence, properties, metallurgy and applications, including its alloys. Third edition. London; 1896, $666 \mathrm{p}$.

16. Laparra M. The aluminium false twins. Charles martin hall and paul héroult's first experiments and technological options. Journal for the History of Aluminium. 2012;48:85-105. 
17. Fedot'ev PP. The current state of the chemical and electrochemical industry on the continent of Europe: monograph. Sankt-Peterburg: Tipolitografiya Shredera; 1907, 229 p. (In Russ.)

18. Griswold T. Electrolytic cell. Patent US, no. 1070454; 1913.

19. Johnson AF. Method of producing aluminum. Patent US, no. $2480474 ; 1949$.

20. Ransley CE. Improvements in or relating to Electrolytic Cells for the Production of Aluminium. Patent GB, no. 802905; 1958.

21. Ransley CE. Producing or Refining Aluminum. Patent US, no. 3028324; 1962.

22. Ransley CE. The Application of the Refractory Carbides and Borides to Aluminum Reduction Cells. In: Extractive Metallurgy of Aluminum. Vol. 2. Aluminium. New York: Interscience; 1962, p. 487-506.

23. Lewis RA. Production of Aluminum. Patent US, no. $2915442 ; 1959$.

24. Dewey JL. Refractory Lining for Alumina Reduction Cells. Patent US, no. 3093570; 1963.

25. Joo LA, Tucker KW, McCown FE. Titanium diboridegraphite composites. Patent US, no. 4376029; 1983.

26. Hudson TJ. Cathode technology for aluminum electrolysis cells. Light Metals. 1987;321-325.

27. Gessing AJ, Wheeler DJ. Screening and avaluation methods of cathode materials for use in aluminum reduction cells in presence of molten aluminum and cryolite up to $1000^{\circ} \mathrm{C}$. Light Metals. 1987;327-334.

28. Mclntyre J, Mitchell DN, Simpson S. Performance testing of cathodic materials and designs in a $16 \mathrm{kA}$ cell and a test bed. Light Metals. 1987;335-344.

29. Tucker KW, Gee JT, Shaner JR, Joo LA, Taberoux AT, Stewart DV, et al. Stable TiB2 - graphite cathode for aluminium production. Light Metals. 1987;345-349.

30. Van Leeuwen TM. An aluminum revolution. In: Equity Research, Credit Suisse First Boston. Boston; 2000, $110 \mathrm{p}$.

31. Brown CW. The wettability of TiB2-based cathodes in low-temperature slurry-electrolyte reduction cells. JOM. 1998;50(5):38-40.
32. Christini RA, Dawless RK, Ray SP, Weirauch DA. Phase III advanced anodes and cathodes utilized in energy efficient aluminum production cells. In: Final Technical Progress Report for the Period 1998 August through 2001 July (Revised 2002 May 07). 92 p. Available from: https://www.osti.gov/servlets/purl/794978 [Accessed 9th August 2020].

33. Bradford DR. Inert Anode Metal Life in Low Temperature Reduction Process. Final Technical Report for September 17, 1998 through March 31, 2005. 101 p. National Technical Reports Library. Available from: https://ntrl.ntis.gov/NTRL/dashboard/searchResults/titleDe tail/DE2006841153.xhtml [Accessed 9th August 2020]. 34. Wang Jia-wei, Lai Yan-qing, Tian Zhong-liang, Liu Yexiang. Effect of electrolysis superheat degree on anticorrosion performance of $5 \mathrm{Cu} /(10 \mathrm{NiO}$ - NiFe2O4) cermet inert anode. Journal of Central South University of Technology. 2007:768.

http://doi.org/10.1007/s11771-007-0146-5

35. Zaikov Yu, Khramov A, Kovrov V, Kryukovsky V, Apisarov A, Chemesov $O$, et al. Electrolysis of aluminum in the low melting electrolytes based on potassium cryolite. Light metals. 2008:505.

36. Hryn JN, Tkacheva OY, Spangenberger JS. UltraHigh-efficiency aluminum production cell. In: Report of Energy Systems Division, Argonne National Laboratory. Award Number: DE-AC0206CH11357. April 2014. P. 86. Available from: https://www.energy.gov/eere/amo/downloads/ultrahighefficiency-aluminum-production-cells [Accessed 17th August 2020].

37. Bao Shengzhong, Chai Dengpeng, Shi Zhirong, Wang Junwei, Liang Guisheng, Zhang Guisheng. Effects of current density on current efficiency in low temperature electrolysis with vertical electrode structure. Light Metals. 2018:611-619. http://doi.org/10.1007/978-3-319-722849_79.

38. Wang Zhaohui, Friis J, Ratvik AP. Transport of Sodium in $\mathrm{TiB}_{2}$ materials investigated by a laboratory test and dft calculations. Light Metals. 2018;1321-1328. http://doi.org/10.1007/978-3-319-72284-9_173

\section{Список литературы}

1. Solheim A. Inert anodes - the blind alley to environmental friendliness? // Light metals. 2018. P. 1253-1260. http://doi.org/10.1007/978-3-319-72284-9_164

2. Горланов Е.С. Электролиз криолитоглиноземных расплавов на твердых катодах // XI Междунар. конгр. «Цветные металлы и минералы» и XXXVII Междунар. конф. «ИКСОБА»: сб. докл. (г. Красноярск, 16-20 сентября 2019). Красноярск, 2019. С. 275-288.

3. Горланов Е.С. Особенности применения твердых электродов для электролиза криолитоглиноземных расплавов // Вестник Иркутского государственного технического университета. 2019. Т. 23. № 2. С. 356366. http://doi.org/10.21285/1814-3520-2019-2-356-366

4. Patente no. 175711, France. Procédé électrolytique pour la préparation de l'aluminium / P. L-T. Héroult. Déposé 23.04.1886; publ. 01.09.1886.
5. Patent no. 400766, United States of America. Process of Reducing Aluminum by Electrolysis / Ch. M. Hall; no. 207601. Filed 9.07.1886; publ. 2.04.1889.

6. Patent no. 400664, United States of America. Process of reducing aluminium from its fluoride salts by electrolysis / Ch. M. Hall; no. 226206. Filed 2.02.1887; publ. 2.04.1889.

7. Patent no. 400665, United States of America. Manufacture of aluminium / Ch. M. Hall; no. 282954. Filed 17.08.1888; publ. April 2, 1889. 3 p.

8. Patent no. 400666, United States of America. Process of electrolyzing crude salts of aluminium / Ch. M. Hall; no. 282955. Filed 17.08.1888; publ. 2.04.1889.

9. Patent no. 400667, United States of America. Process of electrolyzing crude salts of aluminium / Ch. M. Hall; no. 286034. Filed 21.09.1888; publ. 2.04.1889. 
10. Minet A. The Production of Aluminium and its Industrial Uses. First edition. London: Chapman \& Hall, 1905. 266 p. 11. Ibl N. Current Distribution / in Comprehensive Treatise of Electrochemistry. Vol. 6. Electrodics: Transport. Eds. by E. Yeager J.O'M. Bockris, B.E. Conway, S. Sarangapani. New York: Plenum Press, 1983. P. 239-315. [Электронный ресурс]. URL:

https://books.google.ru/books/about/Electrodics_transport. html?id=aN-FAAAAIAAJ\&redir_esc=y (09.08.2020).

12. Newman J., Thomas-Alyea K.E. Electrochemical systems. 3rd ed. John Newman and New Jersey. Hoboken: John Wiley \& Sons, 2004. 647 p.

13. Гамбург Ю.Д., Зангари Дж. Теория и практика электроосаждения металлов / пер. с англ. Ю.Д. Гамбург. М.: БИНОМ. Лаборатория знаний, 2015. 441 с.

14. Барабошкин Н.А. Электрокристаллизация металлов из расплавленных электролитов. М.: Наука, 1976. 279 с. 15. Richards J.W. Aluminium: its history, occurrence, properties, metallurgy and applications, including its alloys. Third edition. London, 1896. 666 p.

16. Laparra M. The aluminium false twins. Charles martin hall and paul héroult's first experiments and technological options // Journal for the History of Aluminium. 2012. No. 48. P. 85-105.

17. Федотьев П.П. Современное состояние химической и электрохимической промышленности на континенте Европы: монография. СПб.: Тип.-литогр. Шредера, 1907. 229 с.

18. Patent no. 1070454, United States of America. Electrolytic cell / T. Griswold; Dow Chemical Company; no. 633320. Filed 15.06.1911; publ. 19.08.1913.

19. Patent no. 2480474, United States of America. Int. Cl. 204-67. Method of producing aluminum / Arthur F. Johnson; Reynolds Metals Company; no. 634903. Filed 14.12.1945; publ. 30.08.1949.

20. Patent 802905, Great Britain. Int. Cl. B23n. C22d. Improvements in or relating to Electrolytic Cells for the Production of Aluminium / C.E. Ransley; no. 1155/54. Filed 14.01.1955; publ. 15.10.1958.

21. Patent no. 3028324, United States of America. Int. Cl. 204-67. Producing or Refining Aluminum / C.E. Ransley; British Aluminium Company; no. 660994. Filed 23.05.1957; publ. 23.04.1962.

22. Ransley C.E. The application of the refractory carbides and borides to aluminum reduction cells // Extractive Metallurgy of Aluminum. Vol. 2. Aluminium. New York: Interscience, 1962. P. 487-506.

23. Patent no. 2915442, United States of America. Cl. 204-67. Production of Aluminum / R.A. Lewis; Kaiser Aluminum \& Chemical Corporation; no. 549347. Filed 28.11.1955; publ. 1.12.1959.

24. Patent no. 3093570, United States of America. Int. Cl. 204-243. Refractory Lining for Alumina Reduction Cells / J.L. Dewey; Reynolds Metals Company; no. 847594. Filed 20.10.1959; publ. 11.06.1963.

25. Patent no. 4376029, United States of America. Int. Cl. C25B 11/04, C25C 3/12. Titanium diboride-graphite composites / L.A. Joo, K.W. Tucker, F.E. McCown; Great Lakes Carbon Corporation; No. 186181. Filed 11.09.1980; publ. 8.03.1983

26. Hudson T.J. Cathode technology for aluminum electrolysis cells // Light Metals. 1987. P. 321-325.

27. Gessing A.J., Wheeler D.J. Screening and avaluation methods of cathode materials for use in aluminum reduction cells in presence of molten aluminum and cryolite up to $1000^{\circ} \mathrm{C} / /$ Light Metals. 1987. P. 327-334.

28. Mclntyre J., Mitchell D.N., Simpson S. Performance testing of cathodic materials and designs in a $16 \mathrm{kA}$ cell and a test bed // Light Metals. 1987. P. 335-344.

29. Tucker K.W., Gee J.T., Shaner J.R., Joo L.A., Taberoux A.T., Stewart D.V., et al. Stable TiB2 - graphite cathode for aluminium production // Light Metals. 1987. P. 345-349.

30. Van Leeuwen T.M. An aluminum revolution // Equity Research, Credit Suisse First Boston. Boston: 2000. 110 p. 31. Brown C.W. The wettability of TiB2-based cathodes in low-temperature slurry-electrolyte reduction cells // JOM. 1998. Vol. 50. Issue 5. P. 38-40.

32. Christini R.A., Dawless R.K., Ray S.P., Weirauch D.A. Phase III advanced anodes and cathodes utilized in energy efficient aluminum production cells // Final Technical Progress Report for the Period 1998 August through 2001 July (Revised 2002 May 07). 92 р. [Электронный реcypc]. URL: https://www.osti.gov/servlets/purl/794978 (09.08.2020).

33. Bradford D.R. Inert Anode Metal Life in Low Temperature Reduction Process. Final Technical Report for September 17, 1998 through March 31, 2005. 101 p / National Technical Reports Library [Электронный ресурc]. URL: https:/ntrl.ntis.gov/NTRL/dashboard/searchResults/titleDe tail/DE2006841153.xhtml (09.08.2020).

34. Wang Jia-wei, Lai Yan-qing, Tian Zhong-liang, Liu Yexiang. Effect of electrolysis superheat degree on anticorrosion performance of $5 \mathrm{Cu} /(10 \mathrm{NiO}$ - NiFe2O4) cermet inert anode // Journal of Central South University of Technology. 2007. P. 768.

http://doi.org/10.1007/s11771-007-0146-5

35. Zaikov Yu., Khramov A., Kovrov V., Kryukovsky V., Apisarov A., Chemesov O., et al. Electrolysis of aluminum in the low melting electrolytes based on potassium cryolite // Light metals. 2008. P. 505.

36. Hryn J.N., Tkacheva O.Y., Spangenberger J.S. UltraHigh-efficiency aluminum production cell // Report of Energy Systems Division, Argonne National Laboratory. Award Number: DE-AC02-06CH11357. April 2014. P. 86. [Электронный ресурc]. URL: https://www.energy.gov/eere/amo/downloads/ultrahighefficiency-aluminum-production-cells (17.08.2020).

37. Bao Shengzhong, Chai Dengpeng, Shi Zhirong, Wang Junwei, Liang Guisheng, Zhang Guisheng. Effects of current density on current efficiency in low temperature electrolysis with vertical electrode structure // Light Metals. 2018. P. 611-619. http://doi.org/10.1007/978-3-31972284-9_79

38. Wang Zhaohui, Friis J., Ratvik A.P. Transport of sodium in $\mathrm{TiB}_{2}$ materials investigated by a laboratory test and DFT calculations // Light Metals. 2018. P. 1321-1328. http://doi.org/10.1007/978-3-319-72284-9_173 


\section{INFORMATION ABOUT THE AUTHOR}

\section{Evgeniy S. Gorlanov,}

Doct. Sci. (Eng.),

Deputy General Director of EXPERT-AL LLC, 86/A, Sredniy pr., V.O. Saint-Petersburg

199106, Russia;

$\checkmark$ e-mail: gorlanove@yandex.ru

\section{Contribution of the author}

The author performed the research, made a generalization on the basis of the results obtained and prepared the copyright for publication.

\section{Conflict of interests}

The author declares no conflicts of interests.

The final manuscript has been read and approved by the author.

Information about the article

The article was submitted 08.10.20; approved after reviewing 11.11.2020; accepted for publication 17.12.2020.

\section{СВЕДЕНИЯ ОБ АВТОРЕ}

Горланов Евгений Сергеевич, доктор технических наук, заместитель генерального директора, О०О «ЭКСПЕРТ-АЛ», 199106, г. Санкт-Петербург, Средний просп. В.О., 86/А, Россия; $\checkmark$ e-mail: gorlanove@yandex.ru

\section{Заявленный вклад автора}

Автор выполнил исследовательскую работу, на основании полученных результатов провел обобщение, подготовил рукопись к печати.

\section{Конфрликт интересов}

Автор заявляет об отсутствии конфрликта интересов.

Автор прочитал и одобрил окончательный вариант рукописи.

\section{Информация о статье}

Статья поступила в редакцию 08.10.20; одобрена после рецензирования 11.11.2020; принята к публикации 17.12.2020. 